\title{
SAVING TAXES THROUGH FOREIGN PLANT OWNERSHIP
}

\author{
PETER EGGER \\ WOLFGANG EGGERT \\ HANNES WINNER
}

CESIFO WORKING PAPER No. 1887

CATEgory 1: Public FinanCE

JANUARY 2007

An electronic version of the paper may be downloaded

- from the SSRN website:

- from the RePEc website:

- from the CESifo website:

www.SSRN.com

www.RePEc.org

www.CESifo-group.de 


\title{
SAVING TAXES THROUGH FOREIGN PLANT OWNERSHIP
}

\begin{abstract}
This paper analyzes to which extent foreign plant ownership involves lower tax payments than domestic plant ownership. We employ a model of endogenous foreign subsidiary ownership to derive a set of empirically testable hypotheses about the differential taxation of foreign- and domestically-owned subsidiaries. We assess these hypotheses in a data- set of 33,577 European foreign- and domestically-owned manufacturing plants. We identify a significant tax-saving of endogenous foreign owner- ship. On average, foreign owners pay 594 Euros per employee or about 56 percent less than domestic owners of similar subsidiaries. This effect is larger in thinner markets with fewer plants, in markets with a greater relative presence of foreign owners, and for foreign owners of larger plants.
\end{abstract}

JEL Code: H25, H73, F23, C21.

Keywords: company taxation, multinational firms, propensity score matching.

Peter Egger

Ifo Institute for Economic Research at the University of Munich

Poschingerstr. 5

81679 Munich

Germany egger@ifo.de
Wolfgang Eggert

Department of Economics

University of Paderborn

Warburgerstr. 100

33098 Paderborn

Germany

wolfgang.eggert@uni-paderborn.de

Hannes Winner

Department of Economics and Statistics

University of Innsbruck

Universitaetsstr. 15

6020 Innsbruck

Austria

Hannes.Winner@uibk.ac.at

$8^{\text {th }}$ December 2006 


\section{Introduction}

The host country-specific tax payments of foreign subsidiaries may differ from those of domestic ones for four major reasons: (i) alternative effective tax rates that are composed of parent and host country statutory tax rates and deductions from the tax base, (ii) transfer pricing, (iii) financial policies at the firm-level, and (iv) preferential tax treatment of foreign-owned firms. Each of these reasons has produced its own sub-literature on the theory of taxation of multinationals (see Hines, 1999; Gresik, 2001; Devereux, 2006, for comprehensive surveys). The first one mainly focuses on the (optimal) design of methods of double-taxation relief through tax treaties (see Bond and Samuelson, 1989; Janeba, 1995; Davies, 2003, 2004) and their consequences for multinational profits and the endogenous firm organization (Davies, Egger, and Egger, 2006). The second strand of research analyzes the possibilities of tax avoidance of multinationals through the endogenous choice of prices of intermediate inputs delivered among plants of the same firm to minimize tax payments at the company level (see, e.g., Gordon and Wilson, 1986; Weichenrieder, 1996a; Haufler and Schjelderup, 2000; Bartelsman and Beetsma, 2003; Mintz and Smart, 2004). The third aforementioned line of work determines a multinational firm's optimal debt policy depending on taxation (see, e.g., Grubert and Mutti, 1991; Hines and Rice, 1994; Weichenrieder, 1998; Desai, Foley, and Hines, 2004; Huizinga, Laeven, and Nicodème, 2006). The fourth sub-literature considers the application of distinct tax treatment for domestic and foreign-owned subsidiaries in a given host country, e.g., via reduced statutory tax rates and/or additional tax base allowances (see, e.g., Weichenrieder, 1996b; Keen, 2001; Janeba and Smart, 2003; Haupt and Peters, 2005; Bucovetsky and Haufler, 2006a,b). ${ }^{1}$

The above-mentioned theoretical literature suggests that the tax differential between foreign-owned and domestically-owned firms could be substantial. This paper aims at quantifying the overall tax savings of multinationals in a data-set of 33, 577 foreign- and domestically-owned subsidiaries in 27 European countries. To derive theoretical hypotheses on the nexus between firm organization and tax payments of foreign subsidiaries, we build on the aforementioned work. Yet, we focus on an endogenous choice of a subsidiary's operation mode in terms of foreign versus domestic ownership, while most of the existing work (theoretical and empirical) takes this choice as given. Furthermore, we allude

\footnotetext{
${ }^{1}$ Recently, the OECD and the European Union proposed a 'Code of Conduct' against harmful tax practices in business taxation (OECD, 1998, 2000; Commission of the European Communities, 1998). The underlying objective is to prevent countries from providing preferential tax treatment to multinational firms (see Eggert and Haufler, 2006, for a discussion).
} 
to the role of local (regional) market characteristics such as market thickness as well as firm size for the tax savings of foreign-owned subsidiaries, where previous work focused mainly on a single firm type and a fixed number of (homogeneous) competitors at the host market. Empirically, we apply matching methods to account for the endogeneity of the plant ownership mode. A major finding is that a foreign-owned subsidiary pays substantially lower taxes than its domestically-owned twin. The difference amounts to about 594 Euros per employee or a fraction of 0.2 of their total assets, which corresponds to tax savings of foreign plant ownership of about 56 percent per employee as compared to domestically owned plants.

The remainder of the paper is organized as follows. The subsequent section lays out a stylized theoretical model to derive the empirically testable hypotheses. Section 3 describes the database, the econometric procedures, and the central empirical findings. The last section concludes with a summary of the most important results.

\section{A model of endogenous foreign plant formation and taxation}

To understand the tax incentives when foreign plant ownership is endogenous we develop a simple partial equilibrium model of foreign country which competes for the location of an international producer against a second, low-tax country (a tax haven). Specifically, consider a market located in a foreign country where $N-1$ internationally immobile (local) firms and one internationally mobile firm sell their entire production. The mobile firm may choose serving the foreign market via exports versus setting up a foreign subsidiary there (see Davies, Egger, and Egger, 2006). This decision is determined by the existence of (nontariff) trade costs on exports and the tax rate differential between the foreign and domestic markets affecting foreign subsidiary set-up. Here, we consider a tax on pure profits as typically assumed in previous work (see, e.g., Haufler and Wooton, 1999; Devereux, Lockwood, and Redoano, 2004). In the following, we compute the firm-specific demand (and production) in two different scenarios. In the first state, the international producer serves the foreign market through exports (indicated by subscript $e$ ) and in the second one it sets up a foreign subsidiary, operating as a multinational firm (indicated by subscript $m$ ). Then, we discuss the optimal integration choice (exporting versus going multinational) of the international firm before characterizing fiscal choices by the government. 
Our primary focus is on deriving testable hypotheses to be inferred in the subsequent empirical investigation. Our three main findings are as follows. First, the internationally mobile firm is taxed at a lower rate than an immobile firm operating locally. Second, the existence of trade costs may explain why the mobile firm prefers paying a certain 'tax premium' (i.e., a positive tax rate) and going multinational as compared to exporting in the absence of taxation. Third, the tax premium tends to be larger - hence, the tax rate differential between foreign local firms and the multinational producer is lower - if the internationally mobile firm is relatively important for the economy.

The market price $p$ of the goods supplied in the foreign country is determined by the inverse demand function $p_{s}=\alpha-\beta Q_{s}$, where $s=e, m, \alpha>0$ is a preference parameter and $\beta>0$ reflects market size. Aggregate demand is

$$
Q_{s}=q_{s}+(N-1) q_{s}^{*} \quad s=e, m .
$$

Here, $q_{s}$ is the demand for the mobile firm and $q_{s}^{*}$ is the demand the $N-1$ symmetric local firms are faced with. The costs of production for both modes of ownership are

$$
C\left(q_{s}\right)=f+\gamma q_{s} \quad C\left(q_{s}^{*}\right)=f^{*}+\gamma^{*} q_{s}^{*} \quad s=e, m,
$$

where the first cost element corresponds to fixed costs and the second one denotes variable (marginal) costs.

In this model, we highlight the effects of company taxation on location decisions. International tax differentials are relevant to the extent that a host country's tax rate matters for a firm's investment decision. To capture this issue, we assume that firms are subject to a profit tax according to the source principle. $^{2}$ The multinational firm's decision problem is

$$
\max _{q_{m} \geq 0} \quad \Pi_{m}\left(q_{m}\right)=\left(1-\tau^{* *}\right)\left\{\left(\alpha-\beta Q_{m}-\gamma\right) q_{m}-f_{m}\right\},
$$

where $\tau^{* *}$ is the tax rate on the profits of the mobile firm in the foreign country.

\footnotetext{
${ }^{2}$ Taxation at source applies directly, if countries avoid international double taxation by exempting foreign-earned income from domestic tax. Furthermore, countries relying on the credit method for double taxation relief generally limit the creditable amount of tax payments to the domestic tax burden. Hence, taxation at source is again effective, if the tax rate in the source country of the investment exceeds the tax rate in the home country of the investor. Finally, foreign-earned profits are generally not taxed in the residence country of the investor until they are repatriated. This gives firms an incentive to defer repatriation if the home country employs the tax credit method and if its tax rate is higher than that in the source country. Source taxation will thus again be effective.
} 
The alternative to going multinational is serving the foreign market via exports. In this setting, the consumer price in the foreign country is influenced by the costs of delivering the good to the consumers. These trade costs incorporate all of the differences between countries that render market integration imperfect, e.g., the costs of cross-border transport. There is a fixed trade cost of $t \in[0,1)$ per unit $q$ shipped to the foreign country. The exporting firm's problem becomes

$$
\max _{q_{e} \geq 0} \quad \Pi_{e}\left(q_{e}\right)=(1-\tau)\left\{\left((1-t)\left(\alpha-\beta Q_{e}\right)-\gamma\right) q_{e}-f_{e}\right\}
$$

where $\tau$ is the tax rate on profits levied in the low tax country where the exporter is domiciled. Let us assume that the tax haven has set $\tau=0$. Then, a typical local firm solves

$$
\max _{q_{s}^{*} \geq 0} \quad \Pi_{s}^{*}\left(q_{s}^{*}\right)=\left(1-\tau^{*}\right)\left\{\left(\alpha-\beta Q_{s}-\gamma^{*}\right) q_{s}^{*}-f^{*}\right\} \quad s=e, m,
$$

where $\tau^{*}$ is the tax rate on profits of local firms in the foreign country.

The first-order conditions of the maximization problem determine the reaction functions of firms in the two states

$$
\begin{aligned}
q_{e}=\frac{(1-t)\left(\alpha-(N-1) \beta q_{e}^{*}\right)-\gamma}{2(1-t) \beta} & q_{m}=\frac{\left(\alpha-(N-1) \beta q_{m}^{*}\right)-\gamma}{2 \beta} \\
q_{e}^{*}=\frac{\alpha-\gamma^{*}-\beta q_{e}}{N \beta} & q_{m}^{*}=\frac{\alpha-\gamma^{*}-\beta q_{m}}{N \beta} .
\end{aligned}
$$

We may solve (4) for the Nash equilibrium that constitutes a fixed point of the reaction functions in the exporting state $\left(q_{e}^{N}, q_{e}^{* N}\right)$ and in the international state $\left(q_{m}^{N}, q_{m}^{* N}\right)$ :

$$
\begin{aligned}
q_{e}^{N}=\frac{N \gamma+(t-1)\left(\alpha+(N-1) \gamma^{*}\right)}{(N+1)(t-1) \beta} & q_{e}^{* N}=\frac{(t-1)\left(\alpha-2 \gamma^{*}\right)-\gamma}{(N+1)(t-1) \beta} \\
q_{m}^{N}=\frac{\alpha-N \gamma+(N-1) \gamma^{*}}{(1+N) \beta} & q_{m}^{* N}=\frac{\alpha+\gamma-2 \gamma^{*}}{(1+N) \beta} .
\end{aligned}
$$

To ensure that the reaction functions cross in the non-negative orthant in quantity space, we assume that $\alpha>2 \gamma^{*}$ and restrict our attention to market structures where the number of firms is large enough so that $(N-1) \gamma^{*}>N \gamma$ holds. A reduction of trade costs increases the amount of exports of the international 
firm. For trade cost of

$$
t<1-\frac{N \gamma}{\alpha+(N-1) \gamma^{*}}
$$

a firm's optimal supply is positive. ${ }^{3}$ A last modeling assumption concerns the fixed set-up costs. It is well-known from the literature that the decision of international firms to export versus going multinational depends on the relative size of trade costs and fixed foreign plant set-up costs (Horstmann and Markusen, 1992). Here, we simply assume that fixed costs are sufficiently low to render the set-up of a foreign subsidiary profitable. Using (5) in the profit definition of the mobile firm determines operating profits (net of taxes) in the absence of fixed costs:

$$
\begin{aligned}
\pi_{e} & =(1-\tau) \frac{\left(N \gamma-(1-t)\left(\alpha+(N-1) \gamma^{*}\right)\right)^{2}}{(1+N)^{2}(1-t) \beta} \\
\pi_{m} & =\left(1-\tau^{* *}\right) \frac{\left(\alpha-N \gamma+(N-1) \gamma^{*}\right)^{2}}{(1+N)^{2} \beta}
\end{aligned}
$$

Inspection of (6) shows that operating profits of firms of the same type are identical in the absence of trade costs so that the markets are perfectly integrated. Furthermore, (6) suggests that $t=0$ implies $\pi_{m}=\pi_{e}$, i.e., both firms earn identical profits in the absence of trade costs.

Assume that the international firm chooses the export mode whenever it is indifferent between exporting and going multinational. Subtracting $\pi_{m}$ from $\pi_{e}$ yields a net profit surplus that can be earned through foreign plant set-up as compared to exporting:

$$
\pi_{m}-\pi_{e}=0 \Leftrightarrow \frac{1-\tau^{* *}}{1-\tau}=\theta \text { where } \theta:=\frac{\left(N \gamma+(t-1)\left(\alpha+(N-1) \gamma^{*}\right)\right)^{2}}{(1-t)\left(\alpha-N \gamma+(N-1) \gamma^{*}\right)^{2}}
$$

This arbitrage condition reveals that - given that trade costs are positive $(t>0)$ - the foreign country may charge a higher tax rate than the low-tax country (where $\tau=0$ ) while still leaving the mobile firm indifferent between going multinational and exporting. Hence, there is a 'tax premium' that a multinational producer is willing to pay before switching to exporting, even if the latter does not involve any tax payments. Note that this tax premium is absent with perfect market integration (where $t=0$ ). In the absence of trade costs, we obtain

\footnotetext{
${ }^{3}$ Hence, we assume that the optimal supply of local firms is positive and both exporting and going multinational generates positive profits for the international producer. To keep the analysis simple, we exclude other potential equilibria.
} 
$\theta=1$. Hence, an increase in market integration, defined as a reduction in $t$, reduces the ability of the foreign economy to tax the profits of an international firm. Recalling that the tax on local firms, $\tau^{*}$, is not constrained by international tax arbitrage, we can then directly infer that the foreign country has to reduce the tax rate on the internationally mobile firm below the rate that is faced by local firms in order to attract a multinational producer. ${ }^{4}$ In the empirical analysis, we would therefore expect well integrated European economies to employ lower tax rates on multinational firms than on local firms (Hypothesis $1)$.

Let us next discuss the effects of an increase in the number of firms on the tax premium. There, we obtain

$$
\frac{\partial \theta}{\partial N}=\frac{2 t \gamma\left(\alpha-\gamma^{*}\right)\left(N \gamma-(1-t)\left(\alpha+(N-1) \gamma^{*}\right)\right)}{(1-t)\left(\alpha-N \gamma+(N-1) \gamma^{*}\right)^{3}}<0 \forall t>0 .
$$

Hence, if a foreign country creates a tax savings potential for mobile firms (by setting lower tax rates), we hypothesize that these tax savings are larger if the market is thinner and mobile firms are relatively important for the economy, all else equal (Hypothesis 2).

\section{Empirical analysis}

\subsection{Estimation strategy for the impact of endogenous foreign ownership on subsidiary tax savings}

When estimating the impact of foreign ownership of a subsidiary on tax payments we have to account for the endogeneity of the former, as suggested by the above theoretical model. Econometrically, we have to estimate the impact of an endogenous binary (treatment) variable with entry one if a subsidiary exhibits a foreign ultimate owner and zero else. In this case, the endogeneity accrues to systematic selection of plants into foreign plant ownership. Then, the impact of foreign ownership on an outcome such as plant-level tax payments can neither be estimated from a simple mean comparison of an outcome variable (here, tax payments) between foreign- and domestically-owned plants nor from a regression model where foreign ownership is treated as an exogenous deter-

\footnotetext{
${ }^{4}$ This hypothesis is similar to the findings in Janeba and Peters (1999), who consider a setting where two countries compete for internationally mobile portfolio capital, but at the same time have access to a completely inelastic domestic tax base. There, revenue maximizing governments levy the maximum tax on the immobile domestic tax base, but a zero tax on the internationally mobile portfolio capital. In contrast to Janeba and Peters (1999), we consider an endogenous choice of plant location with imperfectly competitive product markets.
} 
minant of the outcome. The bias of such an exogenous treatment approach is referred to as one of self-selection or selection into treatment (here, foreign plant ownership; see Wooldridge, 2002).

However, the econometrics literature on program evaluation provides several alternative strategies that are able to eliminate the self-selection bias. Each of these strategies hinges on a different set of assumptions. In case that one assumes that foreign plant ownership is determined by a set of variables that are observable, one can stick to estimation procedures that rely on the assumption of (self-)selection on observables. The international economics and industrial economics literatures on the endogenous organization structure of firms identify characteristics that are observable (see, e.g., Girma and Görg, 2006), so that it seems natural to apply a related procedure here. Moreover, with selection on observables there are procedures that rely on a parametric approach and others that adopt a non-parametric approach of treatment effect identification. Obviously, the latter is less restrictive than the former. Matching is such a nonparametric endogenous treatment effect estimator (see Rosenbaum and Rubin, 1983; Angrist, 1998; Dehejia and Wahba, 1999; Heckman, Ichimura, and Todd; 1997, 1998; Rosenbaum, 2002; Rubin, 2006; Heckman, LaLonde, and Smith, 1999; and Morgan and Harding, 2006 provide a survey). In contrast to other procedures, it eliminates the bias from self-selection into treatment by comparing the outcome (here, the tax payments) of the treated (of foreign-owned subsidiaries) not to all untreated observations but only to those that are similar (ideally, they are identical) with regard to a compulsory set of observable determinants of self-selection into treatment. While self-selection leads to meandependence in outcome and a bias of the unconditional mean comparison, conditioning on the set of observables establishes conditional mean-independence (see Wooldridge, 2002) so that the comparison of the mean of the treated to those control observations that are identical except of being untreated is a valid estimator of the treatment effect on outcome.

Hence, matching requires two steps. First, those control units need to be selected that are similar to the treated ones with regard to the underlying set of observables. Again there are alternative procedures available, but it is particularly efficient to collect the information of all observable variables into a single metric, referred to as the propensity score. With a binary treatment indicator, the latter is nothing else than the predicted probability of treatment participation from a binary choice model (e.g., probit, logit, or other nonlinear probability models). 'Similarity' of a control observation to a treated one is 
then determined by the similarity in the predicted treatment participation. ${ }^{5}$ In a second step, one estimates the treatment effect from the average difference in the outcome vectors of the treated and the matched controls.

One can distinguish among different types of matching, depending on the definition of valid control units. Nearest neighbor (also referred to as one-toone) matching uses for each treated observation only a single (or a few identical) control units with the closest difference in propensity score to the treated unit. ${ }^{6}$ Radius matching uses all control observations in the match whose propensity score lies within a given radius around that of the treated unit. Whereas the number of controls is fixed with $k$-nearest neighbor matching independent of the difference in the propensity score between matched and control observations, radius matching establishes a minimum bound on the matching quality while leaving the number of matched controls undetermined. Kernel matching uses more and, eventually, all control units. Yet, in contrast to the exogenous treatment effect estimator, it applies weights to the control observations which decline in the treated-to-control propensity score difference. While each of these estimators is consistent, there is a trade-off between precision and efficiency in small samples. Radius and kernel matching use a larger number of control units than nearest neighbor matching which increases precision. However, kernel matching uses less suited controls - although their weight is small - in estimating treatment effects. The latter can lead to biased causal effects estimates in small samples.

The literature distinguishes among three key concepts of treatment effects. The first one is referred to as the average treatment effect of the treated (ATT). This is the estimated difference in outcome among the actually treated and the controls. For practical purposes this is the effect that one is typically interested in with applied work. In the subsequent empirical analysis, we focus on ATT as well. The second treatment effect concept is the average treatment effect of the untreated (ATU). The latter is the negative of the average difference of the untreated observations' outcome and that of the matched treated units. Hence, ATU reflects a hypothetical effect of treatment on the actually untreated units. Finally, the average treatment effect (ATE) is a weighted average of ATT

\footnotetext{
${ }^{5}$ However, the propensity score is only a valid similarity metric if each and everyone of the underlying observables in the nonlinear probability model is similar between the treated and the 'similar' controls on average. If this is not the case, one needs to eliminate the possible resulting bias by conditioning on the unbalanced observables in the mean comparison of the outcome between the treated and the matched controls (see Blundell and Costa Dias, 2002).

${ }^{6}$ In general, under $k$-nearest neighbor matching one could match $k$ control units onto each treated one.
} 
and ATU, where the shares of the treated and untreated observations serve as weights. ATE reflects the treatment effect for a randomly drawn observation, irrespective of whether it was actually treated or not.

\subsection{Data}

We use the Amadeus database compiled by Bureau van Dijk, which covers financial and ownership statements for about 250,000 private and publiclyowned firms of 34 European countries (including Eastern European economies) since $1991 .^{7}$ We focus on manufacturing firms according to the NACE industry codes reported in the database.

While data are available for consolidated and non-consolidated accounting statements, we exclude the consolidated accounts so that the unit of observation is a subsidiary and each subsidiary's balance sheet positions are identified separately. This enables us to compare the tax payments of similar units that are foreign- versus domestically-owned. We employ a cross-section of the data with averages for the late 1990s. For instance, the latter ensures that we can use information about plants that are only recorded once in the years 1996-2003. The resulting data-set covers a sample of 33,577 subsidiaries. Table 1 summarizes the distribution of the included subsidiaries across 27 European economies, 935 regions, ${ }^{8}$ and 331 NACE 4-digit industries. On average, there are around 1210 (35) firms per country (region), and about 99 firms per industry.

Two pieces of information are central to our analysis: subsidiary-level tax payments as the dependent (or outcome) variable and foreign ownership of subsidiaries as an (endogenous) determinant thereof. As a measure of the former, we use a subsidiary's actual tax payments per employee in Euros and, alternatively, its tax payments to total assets ratio. Information about foreign subsidiary ownership is captured by an indicator variable that is unity for subsidiaries with at least one foreign ultimate owner, and zero else. The descriptive statistics for these variables are summarized at the top of Table 2 .

According to the information there, the average tax payment per employee amounts to about 1, 032 Euros with a corresponding average tax-to-total-assetratio of about 3.1. Around 15 percent of all plants in the sample are foreignowned. The bottom part of the table summarizes descriptive statistics of ob-

\footnotetext{
${ }^{7}$ For the United Kingdom, Germany, France, Italy, Ukraine, and the Russian Federation a firm is included in the Amadeus database if one of the following criteria is fulfilled: operating revenue equals at least 15 million Euros (10 million Euros for the other countries), total assets equal at least 30 million Euros (20 million Euros for the other countries), and the number of employees equals at least 200 (150 for the other countries).

${ }^{8}$ The regional aggregates roughly correspond to NUTS 4-digit units.
} 
Table 1: Allocation of firms across countries, regions, and industries

\begin{tabular}{lccc}
\hline & Countries $^{1)}$ & Regions & $\begin{array}{c}\text { Nace 4-digit } \\
\text { industries }\end{array}$ \\
\hline Number & 27 & 935 & 331 \\
Number of firms: & & & \\
$\quad$ Average & 1212.37 & 35.01 & 98.89 \\
$\quad$ Standard deviation & 1515.39 & 94.23 & 127.88 \\
\hline
\end{tabular}

Notes: The total number of firms is 33577 and consists of foreign-owned subsidiaries in a country and domestic firms.

1) Austria, Belgium, Bosnia-Herzegovina, Bulgaria, Croatia, Cyprus, Czech Republic, Denmark, Ireland, Estonia, France, Germany, Greece, Hungary, Iceland, Italy, Latria, Lithuania, Malta, Netherlands, Poland, Portugal,

Republic of Macedonia, Romania, Russian Federation, Serbia and Montenegro, Slovak Republic, Slovenia, Spain, Sweden, Switzerland,

Ukraine, United Kingdom

Table 2: Descriptive statistics

\begin{tabular}{lrr}
\hline Variables & Mean & Standard dev. \\
\hline Endogenous variables & $1,032.396$ & $34,872.020$ \\
Tax payments per employee & 3.143 & 60.618 \\
Tax payments relative to total assets & 0.151 & 0.358 \\
Foreign multinational plant ownership dummy variable & & \\
& & 24.477 \\
Observables in the selection models & $1,290.898$ & $4,198.332$ \\
Firm age & 10.925 & 26.179 \\
Firm age squared & 0.151 & 0.292 \\
Plants per region and industry & $250,230.900$ & $563,968.100$ \\
Foreign MNE affiliates to national firms per region and industry & 481.661 & 879.419 \\
Employees per region & $2,221,066.000$ & $5,477,029.000$ \\
Number of employees per firm in region and industry & $10,927.470$ & $11,343.950$ \\
Regional worker compensation & $9,974,800.000$ & $7,568,883.000$ \\
Industry level wage cost per employee & & 0.151 \\
Industry level cost of intermediate goods & 477.470 & $1,311.977$ \\
Further variables used with interaction terms & 0.151 & 0.150 \\
Plant-level employment & & \\
Foreign MNE affiliates to national firms per region & & \\
\hline
\end{tabular}


servable explanatory variables of foreign plant ownership. More details on these variables and a rationalization of their use are provided in the next subsection.

\subsection{Estimation and results}

In the following, we estimate the ATT of exhibiting a foreign owner, assuming that foreign owners do not set-up/acquire foreign subsidiaries at random. Therefore, in a first step, we need to determine the probability for a plant to participate in the treatment of exhibiting a foreign owner conditional on a set of observable variables. We estimate three alternative non-linear probability models: a probit model that rests on a normal distribution; a logit model which assumes a logistic distribution function; and a complementary log-log model. ${ }^{9}$ Which one of the nonlinear probability models fit the data best is an empirical - and actually a testable - question.

We determine the probability of exhibiting a foreign owner by the following set of variables: firm age and firm age squared; the number of plants, the ratio of foreign MNE affiliates to domestic firms, and the number of employees per firm in region $r$ and industry $n$; worker compensation in region $r$; wage cost per employee and cost of intermediate goods in industry $n$. It is wellknown that older plants and firms are traditionally bigger and more productive than others so that we assume firm age to be positively correlated with the propensity to exhibit a foreign owner. The region-and industry-specific variables are aggregates of individual level information from the Amadeus database. The region-by-industry plant number, the ratio of foreign MNE affiliates to domestic firms, and the number of employees per firm capture two different kinds of determinants. On the one hand, these variables reflect the overall attractiveness of a market, the thickness at the intermediate goods supplier market, and other linkage effects. On the other hand, these variables capture the thickness at the subsidiary's market and, hence, the competitive pressure for a subsidiary, the pressure at factor markets and other adverse factors for plant location. Hence, it is not feasible to disentangle the stimulating versus impeding effects of foreign ownership of these variables ex ante. Similarly, regional worker compensation or industry characteristics such as the wage cost per employee and expenditures for intermediate goods reflect such stimulating and impeding influences. ${ }^{10}$

\footnotetext{
${ }^{9}$ The cumulative density function (cdf) of the complementary log-log model for a variable $z$ is defined as $F(z)=1-e^{-e^{z}}$ and, at medium probability levels, it strictly lies to the left of the normal or logistic cdf's. The change in probability at $z=0$ is more similar to the normal cdf and higher than that of the logistic cdf.

${ }^{10}$ For instance, wages might measure skill levels of workers and their productivity, but they also might represent sheer cost.
} 
Table 3 summarizes the findings for the three aforementioned non-linear probability models. Overall, the explanatory power is exceptionally high for all three models. However, the pseudo- $R^{2}$ is highest for the probit model which rests on the normal density function. The difference in the log-likelihoods among the three models is high enough to reject the logit and the complementary log-log model significantly at one percent against the probit. Given the good explanatory power of the model, we can be confident to rely on the corresponding propensity score metric to define similarity among the treated and the controls for matching.

While matching is able to eliminate the bias of self-selection, the question is how large this bias actually is with the application at hand. An estimate thereof can be obtained from a comparison of the exogenous treatment effect estimator - i.e., the simple mean comparison in the tax payment outcome variable between the foreign-owned and domestically-owned plants - with the matching estimator reflecting the conditional mean comparison. Table 4 provides this comparison with a nearest-neighbor matching estimator for ATT and two tax payment variables as alternative outcomes: tax payments per employee and tax payments per total assets.

The findings in Table 4 indicate that none of the two exogenous treatment effects is significantly different from zero. By way of contrast, the matching estimates of ATT are substantially larger in absolute value and significantly different from zero at one percent. Hence, with the data-set at hand self-selection into foreign ownership leads to a substantial downward bias in absolute value of the impact of foreign ownership on tax payments. With the nearest-neighbor matching approach we estimate an ATT of foreign ownership on tax payments of approximately -594 Euros per employee, corresponding to tax savings of 56 percent as compared to domestic plants. The ATT on tax payments per total assets amounts to -0.204 . These findings support Hypothesis 1 .

\subsection{Extensions}

The estimates in Table 4 reflect averages. Of course, consistent estimates thereof do not require that there is no variation in the treatment effect across the treated. This variation could even be related systematically to observable variables. ${ }^{11}$ In particular, we conjecture that the individual treatment effect of the treated depends on market thickness measured by the number of plants and

\footnotetext{
${ }^{11}$ For instance, see Wooldridge (2002, pp. 626-629) for a model where ATE varies systematically with observables. A similar approach can be pursued with matching.
} 


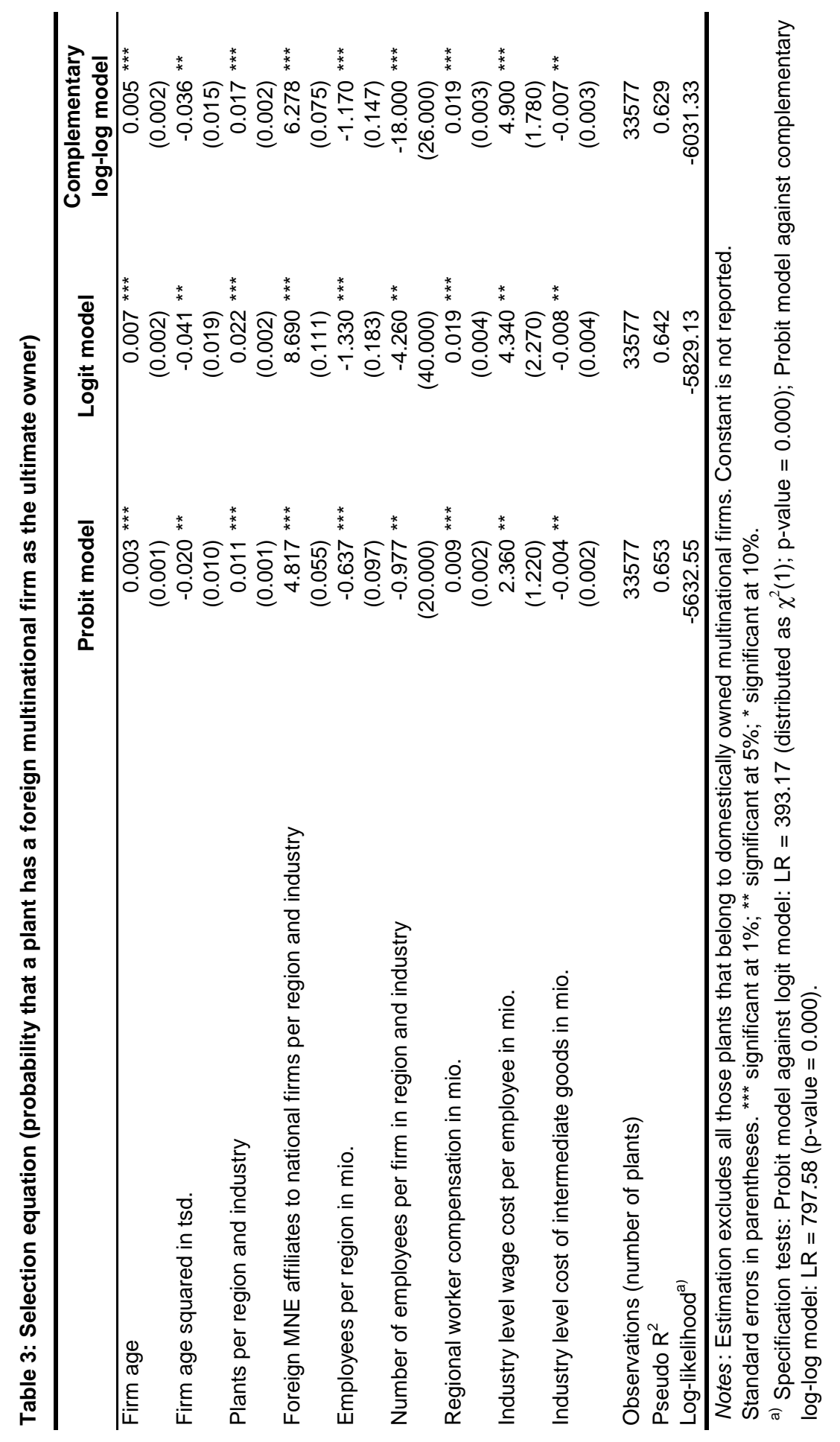




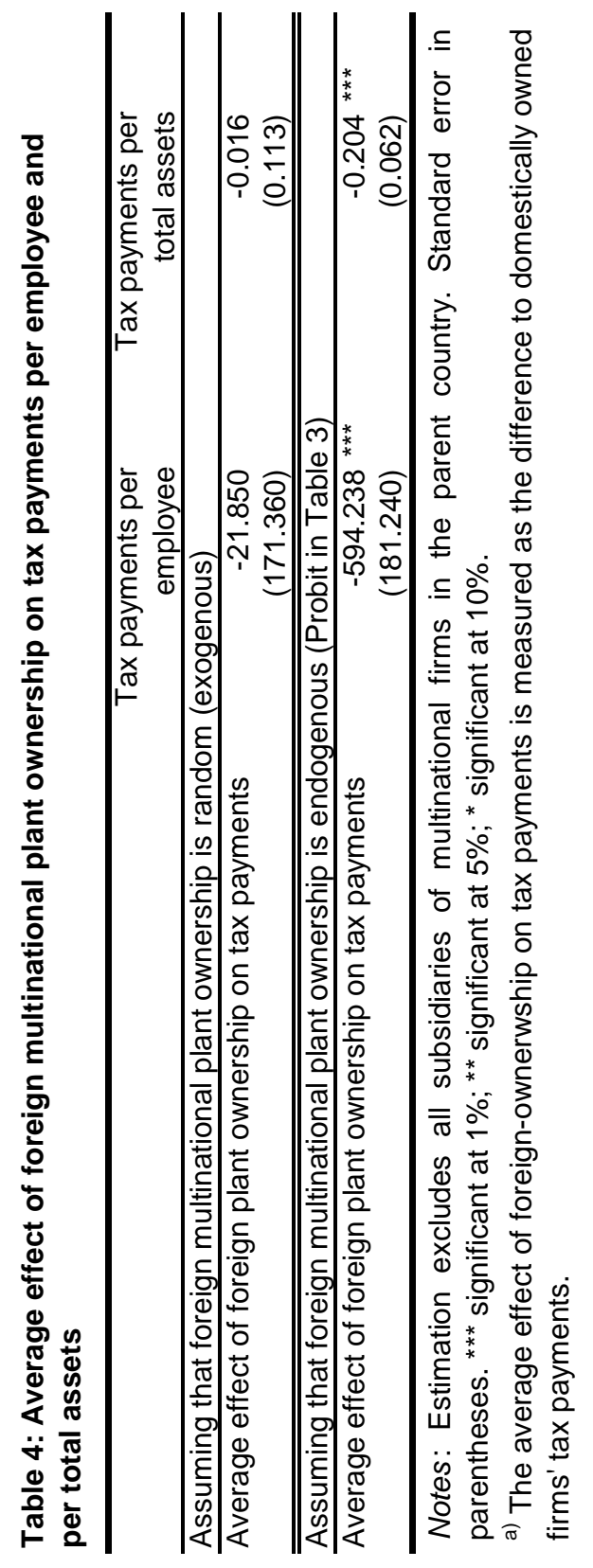


on market attractiveness for multinationals measured by the ratio of foreign to national affiliates in region $r$ and industry $n$ as well as on firm size in terms of the number of employees. A larger market thickness implies less weight for a single foreign owner in the tax base, all else equal. According to Hypothesis 2, we would expect the corresponding tax deductions to be lower and, hence, tax payments to be higher. Relative market attractiveness for MNEs is likely associated with a lower number of producers (e.g., due to economies of scale) and a larger weight of a single MNE in the tax base so that one would conjecture tax payments to rise in market attractiveness for MNEs. Finally, from a bargaining and imperfect labor market perspective which is not reflected in the above model we would hypothesize foreign owners of larger foreign subsidiaries to be able to extract higher rents from the host country tax authorities than smaller foreign owners of subsidiaries. The corresponding results are summarized in Table 5.

Again, we estimate the impact on two alternative tax payment ratios. The determinants involved in the interaction effects with foreign ownership in Table 5 are demeaned as suggested by Wooldridge (2002). We estimate three specifications to illustrate that the explanatory variables used in the interactions are orthogonal enough so that the sign of the interaction effect of ATT is not changed as we augment the specification and, qualitatively, we do not attribute the sign of the impact to, say, market thickness (the number of plants in region $r$ and industry $n$ ), where it should be attributed to one of the other two determinants. The results of this augmented outcome equation indicate that foreign-owned plants in thinner markets with a high fraction of foreign-owned plants pay lower taxes as suggested by Hypothesis 2. Moreover, the tax savings are higher for larger plants.

In the remainder of this section, we consider ATT estimates based on alternative matching procedures, namely radius and kernel matching. Furthermore, we follow Blundell and Costa Dias (2002) by including the number of plants along with the ratio of foreign-owned and domestically-owned subsidiaries per region $r$ and industry $n$ as control variables in the outcome equation, since they are significantly different at five percent between the treated and the matched controls (see Blundell and Costa Dias, 2002). ${ }^{12}$ Table 6 summarizes the corresponding results.

\footnotetext{
${ }^{12}$ Table 7 in the Appendix provides tests on the balancing of the observable variables used in the selection models among the treated and the matched control subsidiaries. According to that table, two variables are significantly different among these sub-samples of the data at five percent: the number of plants per region and industry and the ratio of foreign- to domestically-owned subsidiaries in the same region and industry.
} 


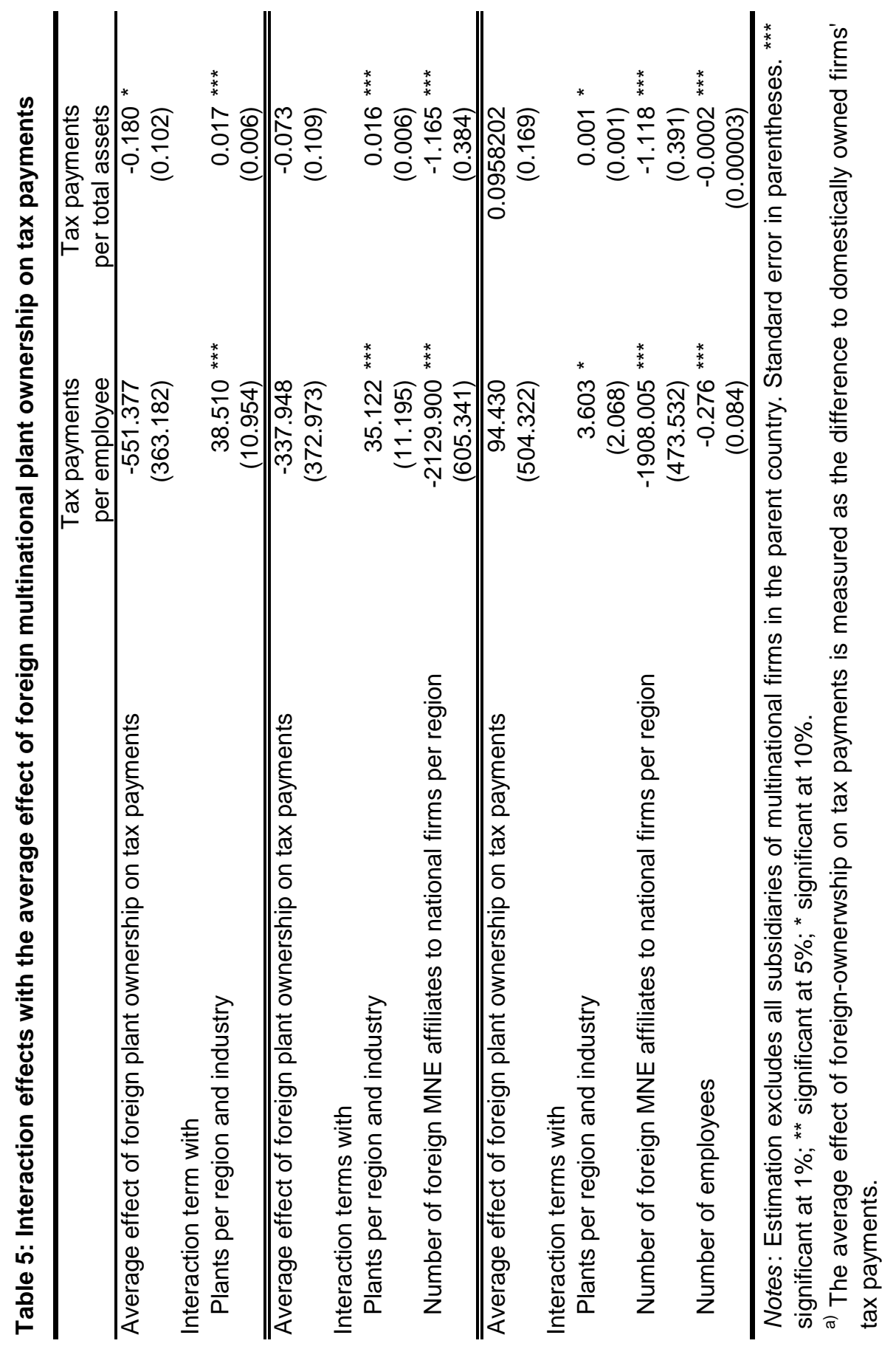


Table 6: Sensitivity analysis (including controls in the regressions that are significant at 10 percent in Table 8) (Including controls in the regressions that are significant at 10 percent in Table 7 and using alternative estimators)

\begin{tabular}{|c|c|c|}
\hline & $\begin{array}{l}\text { Tax payments } \\
\text { per employee }\end{array}$ & $\begin{array}{r}\text { Tax payments } \\
\text { per total assets }\end{array}$ \\
\hline \multicolumn{3}{|l|}{ Nearest neighbor matching } \\
\hline Average effect of foreign plant ownership on tax payments & $\begin{array}{l}-591.243^{*} \\
(362.780)\end{array}$ & $\begin{array}{l}-0.203^{* *} \\
(0.101)\end{array}$ \\
\hline Average effect of foreign plant ownership on tax payments & $\begin{array}{r}-446.738 \\
(380.027)\end{array}$ & $\begin{array}{r}-0.159 \\
(0.109)\end{array}$ \\
\hline \multicolumn{3}{|l|}{ Interaction terms with } \\
\hline Plants per region and industry & $\begin{array}{r}17.950 \\
(13.855)\end{array}$ & $\begin{array}{r}0.010 \\
(0.007)\end{array}$ \\
\hline Number of foreign MNE affiliates to national firms per region & $\begin{array}{l}-1251.913 \text { * } \\
(701.934)\end{array}$ & $\begin{array}{l}-0.777^{*} \\
(0.416)\end{array}$ \\
\hline Plant-level number of employees & $\begin{array}{l}-0.256 \text { *** } \\
(0.078) \\
\end{array}$ & $\begin{array}{l}0.000 \text { *** } \\
(0.000)\end{array}$ \\
\hline \multicolumn{3}{|l|}{ Radius matching (radius = 0.0005) } \\
\hline Average effect of foreign plant ownership on tax payments & $\begin{array}{l}-468.875^{*} \\
(264.875)\end{array}$ & $\begin{array}{l}-0.1866^{* \star} \\
(0.084)\end{array}$ \\
\hline Average effect of foreign plant ownership on tax payments & $\begin{array}{r}-318.907 \\
(282.812)\end{array}$ & $\begin{array}{l}-0.115 \\
(0.093)\end{array}$ \\
\hline \multicolumn{3}{|l|}{ Interaction terms with } \\
\hline Plants per region and industry & $\begin{array}{r}16.512 \\
(13.302)\end{array}$ & $\begin{array}{r}0.004 \\
(0.007)\end{array}$ \\
\hline Number of foreign MNE affiliates to national firms per region & $\begin{array}{l}-1434.762 * * \\
(729.705)\end{array}$ & $\begin{array}{l}-0.810 \text { * } \\
(0.418)\end{array}$ \\
\hline Plant-level number of employees & $\begin{array}{l}-0.268 \text { *** } \\
(0.090)\end{array}$ & $\begin{array}{l}-0.0002^{* * *} \\
(0.00003)\end{array}$ \\
\hline \multicolumn{3}{|l|}{$\overline{~ K e r n e l ~ m a t c h i n g ~(E p a n e c h n i k o v ~ k e r n e l ; ~ b a n d w i d t h ~=~ 0.01) ~}$} \\
\hline Average effect of foreign plant ownership on tax payments & $\begin{array}{l}-375.196 \text { * } \\
(222.597)\end{array}$ & $\begin{array}{l}-0.384 \text { ** } \\
(0.160)\end{array}$ \\
\hline Average effect of foreign plant ownership on tax payments & $\begin{array}{r}113.793 \\
(215.665)\end{array}$ & $\begin{array}{l}-0.265^{\text {** }} \\
(0.114)\end{array}$ \\
\hline \multicolumn{3}{|l|}{ Interaction terms with } \\
\hline Plants per region and industry & $\begin{array}{l}38.7622^{* * *} \\
(11.310)\end{array}$ & $\begin{array}{l}0.018 \text { ** } \\
(0.008)\end{array}$ \\
\hline Number of foreign MNE affiliates to national firms per region & $\begin{array}{l}-2374.149 * * * \\
(629.883)\end{array}$ & $\begin{array}{l}-0.395 \\
(0.406)\end{array}$ \\
\hline Plant-level number of employees & $\begin{array}{l}-0.244^{* * *} \\
(0.073)\end{array}$ & $\begin{array}{l}-0.0002^{* * *} \\
(0.00004)\end{array}$ \\
\hline
\end{tabular}

Notes: Estimation excludes all subsidiaries of multinational firms in the parent country. Standard error in parentheses.

${ }^{* * *}$ significant at $1 \%$; ${ }^{* *}$ significant at $5 \% ;{ }^{*}$ significant at $10 \%$.

a) The average effect of foreign-ownerwship on tax payments is measured as the difference to domestically owned firms' tax payments. 
We find that, in qualitative as well as quantitative terms, the unbalancedness of the number of plants and the ratio of foreign-owned and domestically-owned subsidiaries does not affect the ATT estimates (compare the figures at the top of Table 6 with those at the bottom in Table 4). Similar conclusions apply for the signs of the interaction terms, where conditioning on the unbalanced observables only slightly reduces the precision of the interaction term parameter estimates (compare the nearest-neighbor matching results in Table 6 with those at the bottom in Table 5). Finally, the findings of the nearest-neighbor matching estimator are similar to those of a radius matching or a kernel matching estimator (compare the results at the top of Table 6 to the other ones in that table). ${ }^{13}$ Obviously, the efficiency of the kernel matching estimator leads to higher significance levels for the parameter estimates as with nearest-neighbor or radius matching.

\section{Conclusions}

The tax payments between the average foreign-owned subsidiary and a domestically-owned twin are significantly different in Europe. There are several possible reasons for such a discrepancy, ranging from firm-level policies such as profit shifting to tax authority policies such as preferential treatment. In the theoretical model we concentrate on the latter to derive a set of empirically testable hypotheses about the determinants of the gap in tax payments from a model with imperfect product markets.

Our main goal is providing a quantification of the tax savings through foreign plant ownership. We employ data on 33,577 plants in 27 European economies between 1996 and 2003 to estimate the average tax savings effect of foreign plant ownership, while considering endogenous selection of foreign ownership. Our estimates suggest a savings effect of 594 Euros per employee or about 56 percent as compared to domestically-owned subsidiaries. For larger plants and ones in thinner markets with a strong relative importance of foreign ownership the tax savings effect is even higher. These findings are robust both in qualitative and in quantitative terms to alternative estimation procedures and other sensitivity checks.

\footnotetext{
${ }^{13}$ We use a quite small radius of 0.0005 to ensure a high quality of the matches. Then, for a foreign-owned subsidiary with an estimated 90 percent foreign ownership probability only those domestically-owned subsidiaries with a probability in the interval [0.8995, 0.9005] are used as matches. With kernel matching, we employ an Epanechnikov kernel using a bandwidth of 0.01 .
} 


\section{References}

Angrist, J.D., 1998. Estimating labor market impact of voluntary military service using social security data, Econometrica 66, 249-288.

Bartelsman, E.J. and R.M.W.J. Beetsma, 2003. Why pay more? Corporate tax avoidance through transfer pricing in OECD countries, Journal of Public Economics 87, 2225-2252.

Blundell, R.W. and M. Costa Dias, 2002. Alternative approaches to evaluation in empirical microeconometrics, Portuguese Economic Journal 1, 91-115.

Bond, E.W. and L. Samuleson, 1989. Strategic behavoir and the rules for international taxation of capital, The Economic Journal 99, 1099-1111.

Bucovetsky, S. and A. Haufler, 2006a. Tax competition when firms choose their organizational form: Should tax loopholes for multinationals be closed? unpublished maunscript, York University and University of Munich.

Bucovetsky, S. and A. Haufler, 2006b. Preferential tax regimes with asymmetric countries, unpublished maunscript, York University and University of Munich.

Commission of the European Communities, 1998. Conclusions of the ECOFIN Council meeting on 1 December 1997 concerning taxation policy (including code of conduct for business taxation), Official Journal of the European Communities 98/C 2/01, Brussels.

Davidson, R. and J.G. MacKinnon, 2004. Econometric theory and methods, New York: Oxford University Press.

Davies, R.B., 2003. The OECD model tax treaty: Tax competition and twoway capital flows, International Economic Review 44, 725-753.

Davies, R.B., 2004. Tax treaties and foreign direct investment: Potential versus performance, International Tax and Public Finance 11, 775-802.

Davies, R.B., H. Egger, and P. Egger, 2006. Tax competition for international producers and the mode of market entry, unpublished manuscript, University of Oregon.

Dehejia, R. and S. Wahba, 1999. Causal effects in non-experimental studies: Reevaluating the evaluation of training programmes, Journal of the American Statistical Association, forthcoming.

Desai, M.A., C.F. Foley, and J.R. Hines, 2004. A multinational perspective on capital structure choice and internal markets, Journal of Finance 59, 24512487 .

Devereux, M.P., 2006. The impact of taxation on the location of capital, firms and profit: A survey of empirical evidence, unpublished manuscript, University of Warwick. 
Devereux, M.P., B. Lockwood and M. Redoano, 2004, Do countries compete over corporate tax rates, unpublished manuscript, University of Warwick.

Eggert, W. and A. Haufler, 2006. Company tax coordination cum tax rate competition in the European Union, FinanzArchiv forthcoming.

Frölich, M., 2004. Programme evaluation with multiple treatments, Journal of Economic Surveys 18, 181-224.

Girma, S. and H. Görg, 2006. Evaluating the foreign ownership wage premium using a difference-in-differences matching approach, Journal of International Economics, forthcoming.

Gordon, R.H. and J.D. Wilson, 1986. An examination of multijurisdictional corporate income taxation under formula apportionment, Econometrica $54,1357-1373$.

Gresik, T.A., 2001. The taxing task of taxing transnationals, Journal of Economic Literature 39, 800-838.

Grubert, H. and J. Mutti, 1991. Taxes, tariffs and transfer pricing in multinational corporate decision making, Review of Economics and Statistics 73, 285-293.

Haufler, A. and I. Wooton, 1999. Country Size and Tax Competition For Foreign Direct Investment, Journal of Public Economics 71, 121-139.

Haufler, A. and G. Schjelderup, 2000. Corporate tax systems and cross country profit shifting, Oxford Economic Papers 52, 306-325.

Haupt, A. and W. Peters, 2005. Restricting preferential tax regimes to avoid harmful tax competition. Regional Science and Urban Economics 35, 493507.

Heckman, J.J., H. Ichimura, and P. Todd, 1997. Matching as an econometric evaluation estimator: Evidence from a job training programme, Review of Economic Studies 64, 605-654.

Heckman, J.J., H. Ichimura, and P. Todd, 1998. Matching as an Econometric Evaluation Estimator, Review of Economic Studies 65, 261-294.

Heckman, J.J., R.J. LaLonde, and J.A. Smith, 1999. The economics and econometrics of active labor market programs, in O. Ashenfelter and D. Card (eds.), Handbook of labor economics, Vol. 3A, Amsterdam et al.: Elsevier Science, North-Holland, 1865-2097.

Hines, J.R., 1999. Lessons from behavioral responses to international taxation, National Tax Journal 52, 304-322.

Hines, J.R. and E.M. Rice, 1994. Fiscal paradise: Foreign tax havens and American business, Quarterly Journal of Economics 109, 149-182. 
Horstmann, I. J. and J. R. Markusen, 1992. Endogenous market structures in international trade (natura facit sltum), Journal of International Economics 32, 109-129.

Huizinga, H., L. Laeven, and G. Nicodème, 2006. Capital structure and international debt shifting, unpublished manuscript.

Janeba, E., 1995. Corporate income tax competition, double taxation treaties, and foreign direct investment, Journal of Public Economics 56, 311-326.

Janeba, E. and W. Peters, 1999. Tax evasion, tax competition and the gains from nondiscrimination: The case of interest taxation in Europe, The Economic Journal 109, 93-101.

Janeba, E. and M. Smart, 2003. Is targeted tax competition less harmful than its remedies? International Tax and Public Finance 10, 259-280.

Keen, M., 2001. Preferential regimes can make tax competition less harmful, National Tax Journal 54, 757-762.

Mintz, J. and M. Smart, 2004. Income shifting, investment, and tax competition: Theory and evidence from provincial taxation in Canada, Journal of Public Economics 88, 1149-1168.

Morgan, S.L. and D.J. Harding, 2006. Matching estimators of causal effects: Prospects and pitfalls in theory and practice, Sociological Methods and Research 35, 3-60.

OECD, 1998. Harmful tax competition: An emerging global issue, Paris: Organisation for Economic Cooperation and Development.

OECD, 2000. Towards global tax cooperation. Progress in identifying and eliminating harmful tax practices. Paris: Organisation for Economic Cooperation and Development.

Rosenbaum, P.R. and D.B. Rubin, 1983. The central role of the propensity score in observational studies for causal effects, Biometrika 70, 41-55.

Rosenbaum, P.R., 2002. Observational studies, 2nd ed., New York: SpringerVerlag.

Rubin, D.B., 2006. Matched sampling for causal effects. New York: Cambridge University Press.

Weichenrieder, A.J., 1996a. Transfer pricing, double taxation, and the cost of capital, Scandinavian Journal of Economics 98, 445-452.

Weichenrieder, A.J., 1996b. Fighting international tax avoidance: The case of Germany, Fiscal Studies 17, 37-58.

Weichenrieder, A.J., 1998. Foreign profits and domestic investment, Journal of Public Economics 69, 451-463.

Wooldridge, J.M., 2002, Econometric analysis of cross-section and panel data, Cambridge, MA: MIT Press. 


\section{Appendix}

Table 7 investigates the balancing property for the observable variables employed in the selection equation models to determine the probability for a subsidiary to be foreign-owned. Of all determinants, only two were significantly different at five percent among the treated (foreign-owned) and the matched control subsidiaries. To avoid any associated bias with this, we estimate treatment effects where we condition on these variables to eliminate their influence as suggested by Blundell and Costa Dias (2002). 


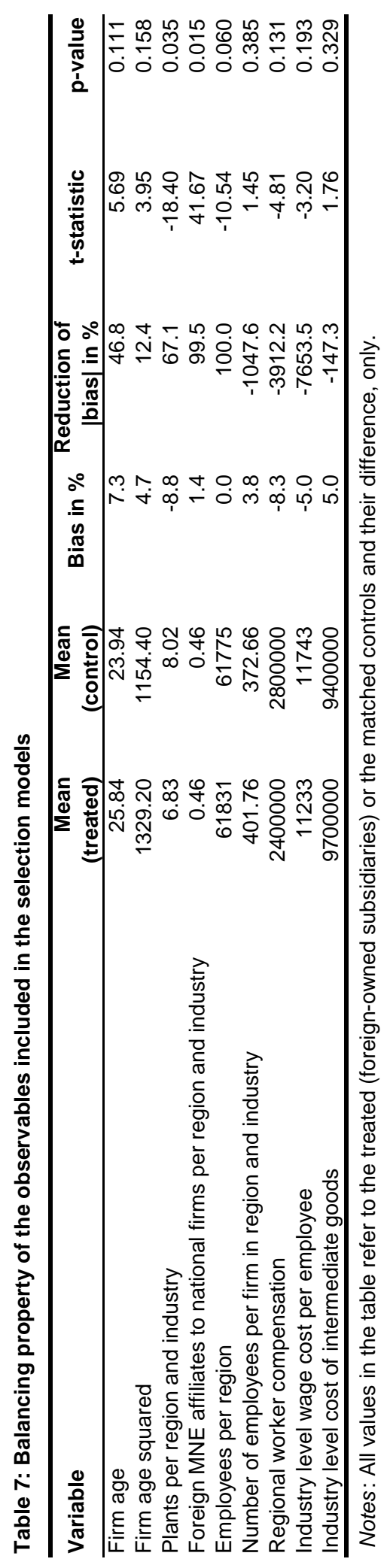




\section{CESifo Working Paper Series}

(for full list see www.cesifo-group.de)

1828 Eytan Sheshinski, Longevity and Aggregate Savings, October 2006

1829 Momi Dahan and Udi Nisan, Low Take-up Rates: The Role of Information, October 2006

1830 Dieter Urban, Multilateral Investment Agreement in a Political Equilibrium, October 2006

1831 Jan Bouckaert and Hans Degryse, Opt In Versus Opt Out: A Free-Entry Analysis of Privacy Policies, October 2006

1832 Wolfram F. Richter, Taxing Human Capital Efficiently: The Double Dividend of Taxing Non-qualified Labour more Heavily than Qualified Labour, October 2006

1833 Alberto Chong and Mark Gradstein, Who's Afraid of Foreign Aid? The Donors' Perspective, October 2006

1834 Dirk Schindler, Optimal Income Taxation with a Risky Asset - The Triple Income Tax, October 2006

1835 Andy Snell and Jonathan P. Thomas, Labour Contracts, Equal Treatment and WageUnemployment Dynamics, October 2006

1836 Peter Backé and Cezary Wójcik, Catching-up and Credit Booms in Central and Eastern European EU Member States and Acceding Countries: An Interpretation within the New Neoclassical Synthesis Framework, October 2006

1837 Lars P. Feld, Justina A.V. Fischer and Gebhard Kirchgaessner, The Effect of Direct Democracy on Income Redistribution: Evidence for Switzerland, October 2006

1838 Michael Rauscher, Voluntary Emission Reductions, Social Rewards, and Environmental Policy, November 2006

1839 Vincent Vicard, Trade, Conflicts, and Political Integration: the Regional Interplays, November 2006

1840 Erkki Koskela and Mikko Puhakka, Stability and Dynamics in an Overlapping Generations Economy under Flexible Wage Negotiation and Capital Accumulation, November 2006

1841 Thiess Buettner, Michael Overesch, Ulrich Schreiber and Georg Wamser, Taxation and Capital Structure Choice - Evidence from a Panel of German Multinationals, November 2006 
1842 Guglielmo Maria Caporale and Alexandros Kontonikas, The Euro and Inflation Uncertainty in the European Monetary Union, November 2006

1843 Jan K. Brueckner and Ann G. Largey, Social Interaction and Urban Sprawl, November 2006

1844 Eytan Sheshinski, Differentiated Annuities in a Pooling Equilibrium, November 2006

1845 Marc Suhrcke and Dieter Urban, Are Cardiovascular Diseases Bad for Economic Growth?, November 2006

1846 Sam Bucovetsky and Andreas Haufler, Preferential Tax Regimes with Asymmetric Countries, November 2006

1847 Luca Anderlini, Leonardo Felli and Andrew Postlewaite, Should Courts always Enforce what Contracting Parties Write?, November 2006

1848 Katharina Sailer, Searching the eBay Marketplace, November 2006

1849 Paul De Grauwe and Pablo Rovira Kaltwasser, A Behavioral Finance Model of the Exchange Rate with Many Forecasting Rules, November 2006

1850 Doina Maria Radulescu and Michael Stimmelmayr, ACE vs. CBIT: Which is Better for Investment and Welfare?, November 2006

1851 Guglielmo Maria Caporale and Mario Cerrato, Black Market and Official Exchange Rates: Long-Run Equilibrium and Short-Run Dynamics, November 2006

1852 Luca Anderlini, Leonardo Felli and Andrew Postlewaite, Active Courts and Menu Contracts, November 2006

1853 Andreas Haufler, Alexander Klemm and Guttorm Schjelderup, Economic Integration and Redistributive Taxation: A Simple Model with Ambiguous Results, November 2006

1854 S. Brock Blomberg, Thomas DeLeire and Gregory D. Hess, The (After) Life-Cycle Theory of Religious Contributions, November 2006

1855 Albert Solé-Ollé and Pilar Sorribas-Navarro, The Effects of Partisan Alignment on the Allocation of Intergovernmental Transfers. Differences-in-Differences Estimates for Spain, November 2006

1856 Biswa N. Bhattacharyay, Understanding the Latest Wave and Future Shape of Regional Trade and Cooperation Agreements in Asia, November 2006

1857 Matz Dahlberg, Eva Mörk, Jørn Rattsø and Hanna Ågren, Using a Discontinuous Grant to Identify the Effect of Grants on Local Taxes and Spending, November 2006

1858 Ernesto Crivelli and Klaas Staal, Size and Soft Budget Constraints, November 2006 
1859 Jens Brøchner, Jesper Jensen, Patrik Svensson and Peter Birch Sørensen, The Dilemmas of Tax Coordination in the Enlarged European Union, November 2006

1860 Marcel Gérard, Reforming the Taxation of Multijurisdictional Enterprises in Europe, "Coopetition" in a Bottom-up Federation, November 2006

1861 Frank Blasch and Alfons J. Weichenrieder, When Taxation Changes the Course of the Year - Fiscal Year Adjustments and the German Tax Reform 2000/2001, November 2006

1862 Hans Jarle Kind, Tore Nilssen and Lars Sørgard, Competition for Viewers and Advertisers in a TV Oligopoly, November 2006

1863 Bart Cockx, Stéphane Robin and Christian Goebel, Income Support Policies for PartTime Workers: A Stepping-Stone to Regular Jobs? An Application to Young LongTerm Unemployed Women in Belgium, December 2006

1864 Sascha O. Becker and Marc-Andreas Muendler, The Effect of FDI on Job Separation, December 2006

1865 Christos Kotsogiannis and Robert Schwager, Fiscal Equalization and Yardstick Competition, December 2006

1866 Mikael Carlsson, Stefan Eriksson and Nils Gottfries, Testing Theories of Job Creation: Does Supply Create Its Own Demand?, December 2006

1867 Jacques H. Drèze, Charles Figuières and Jean Hindriks, Voluntary Matching Grants Can Forestall Social Dumping, December 2006

1868 Thomas Eichner and Marco Runkel, Corporate Income Taxation of Multinationals and Unemployment, December 2006

1869 Balázs Égert, Central Bank Interventions, Communication and Interest Rate Policy in Emerging European Economies, December 2006

1870 John Geweke, Joel Horowitz and M. Hashem Pesaran, Econometrics: A Bird's Eye View, December 2006

1871 Hans Jarle Kind, Marko Koethenbuerger and Guttorm Schjelderup, Taxation in TwoSided Markets, December 2006

1872 Hans Gersbach and Bernhard Pachl, Cake Division by Majority Decision, December 2006

1873 Gunther Schnabl, The Evolution of the East Asian Currency Baskets - Still Undisclosed and Changing, December 2006

1874 Horst Raff and Michael J. Ryan, Firm-Specific Characteristics and the Timing of Foreign Direct Investment Projects, December 2006 
1875 Jukka Pirttilä and Håkan Selin, How Successful is the Dual Income Tax? Evidence from the Finnish Tax Reform of 1993, December 2006

1876 Agnieszka Stążka, Sources of Real Exchange Rate Fluctuations in Central and Eastern Europe - Temporary or Permanent?, December 2006

1877 Xavier Calsamiglia, Teresa Garcia-Milà and Therese J. McGuire, Why do Differences in the Degree of Fiscal Decentralization Endure?, December 2006

1878 Natacha Gilson, How to be Well Shod to Absorb Shocks? Shock Synchronization and Joining the Euro Zone, December 2006

1879 Scott Alan Carson, Modern Health Standards for Peoples of the Past: Biological Conditions by Race in the American South, 1873 - 1919, December 2006

1880 Peter Huber, Michael Pfaffermayr and Yvonne Wolfmayr, Are there Border Effects in the EU Wage Function?, December 2006

1881 Harry Flam and Håkan Nordström, Euro Effects on the Intensive and Extensive Margins of Trade, December 2006

1882 Panu Poutvaara and Mikael Priks, Hooliganism in the Shadow of the 9/11 Terrorist Attack and the Tsunami: Do Police Reduce Group Violence?, December 2006

1883 Ruud A. de Mooij and Gaëtan Nicodème, Corporate Tax Policy, Entrepreneurship and Incorporation in the EU, December 2006

1884 Johannes Becker and Clemens Fuest, Corporate Tax Policy and International Mergers and Acquisitions - Is the Tax Exemption System Superior?, January 2007

1885 Momi Dahan and Udi Nisan, The Effect of Benefits Level on Take-up Rates: Evidence from a Natural Experiment, January 2007

1886 José García-Solanes, Francisco I. Sancho-Portero and Fernando Torrejón-Flores, Beyond the Salassa-Samuelson Effect in some New Member States of the European Union, January 2007

1887 Peter Egger, Wolfgang Eggert and Hannes Winner, Saving Taxes Through Foreign Plant Ownership, January 2007 